\title{
Adaptations and Lessons from COVID-19: A Perspective on How some Industries will be Impacted
}

\author{
Amar Velic ${ }^{1,2}$, Alka Jaggessar ${ }^{1,2}$, Senevirathne Wickramasooriya Mudiyanselage Amal Ishantha \\ Senevirathne ${ }^{1,2}$, Asha Mathew ${ }^{1,2}$, Phani Kumari Paritala ${ }^{1,2}$, Majedul Islam ${ }^{1}$, Arpana Gopi Panicker,2, \\ Karthika Prasad ${ }^{1,2}$, Tejasri Yarlagadda ${ }^{2}$, Kirsten Spann², Jafar Hasan ${ }^{1,2}$, Prasad KDV Yarlagadda ${ }^{1,2, *}$ \\ ${ }^{1}$ Science and Engineering Faculty, Queensland University of Technology, Brisbane, QLD Australia 4000 \\ ${ }^{2}$ Institute of Health and Biomedical Innovation, Faculty of Health, Queensland University of Technology, Kelvin Grove, QLD \\ Australia 4059
}

*Corresponding author: E-mail: y.prasad@qut.edu.au

DOI: 10.5185/amlett.2020.071533

Since the advent of the novel coronavirus disease (COVID-19), various industrial sectors have been significantly affected. Considering the widespread threat of the SARS-CoV-2 virus, scientists worldwide have been working at a rapid pace to understand the virus, develop vaccines and find possible treatment options. Drastic public health measures such as social distancing, use of PPE, quarantine and complete lockdown have been implemented globally to minimize the spread of the virus. Whilst these measures currently seem the only plausible option, they come at the price of compromised economies. Though there are many collaterally affected industries, this review paper highlights current and forecasted changes in manufacturing, medical, climate change, energy and food processing sectors. Some of these sectors have been positively impacted, such as climate change, whilst others have experienced mixed consequences. Some also face an uphill rebuilding processes, which needs to begin sooner rather than later. This paper highlights important recent developments and perspectives on how industries may adapt and learn from COVID-19.

\section{Introduction}

Clusters of the novel coronavirus disease (COVID-19) were first reported in December 2019 in Wuhan, China. The disease quickly propagated in China and abroad, with the Word Health Organization (WHO) declaring a 'Public Health Emergency' and 'Global Pandemic' by January and March 2020, respectively [1]. At present, the underlying virus (SARS-CoV-2) has spread to over 200 countries where it has affected a minimum 6 million people of which approximately 330,000 have died as a result [2]. The potential for this severe (and potentially lethal) illness, in combination with high ease of transmission makes the virus highly dangerous and clinically burdensome $[\mathbf{3 , 4}]$. This has necessitated use of quarantine, social distancing, isolation and other broad-sweeping restrictive measures to limit viral spread [5]. These measures have helped certain highperforming health systems adapt to the pressures of COVID-19 but even still, some have buckled [6,7]. Moreover, these measures have had undeniable, farreaching consequences for industries and sectors quite diverse from the virus itself. This speaks to a major underlying struggle in the management of the pandemic which in many ways, pits health risks against economic costs $[\mathbf{8 , 9}]$.

Evidence of this struggle can be seen in various industries and sectors. Tourism, for instance, is one of the worst hit sectors given that it effectively cannot function in the context of border closures and travel restrictions [10].
The same is true for parts of the transport sector, most notably aviation, where flight bans may shrink the world's gross domestic product by up to $1.67 \%$ [11]. Similarly, social distancing is fundamentally at odds with hospitality, a sector which has seen drastic disruption and job loss [12]. The sports industry and education sector have also been impacted directly by restriction measures, and have both received significant media and research coverage $[\mathbf{1 3 , 1 4}]$.

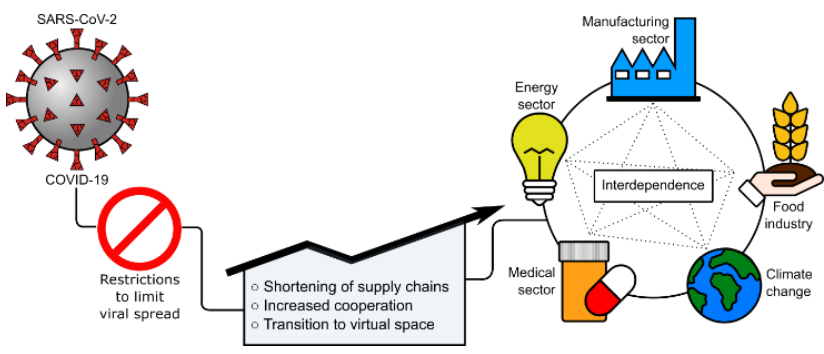

Fig. 1. Knock-on effects of the COVID-19 pandemic. Restrictions in place to curb the spread of SARS-CoV-2 are eliciting broad, global trends such as the shortening of global supply chains and transition to virtual interactions and settings. These trends are impacting various industries and sectors either directly, or indirectly via a complex web of economic interdependence.

Instead of these well-reported impacts, the present review focuses on a select few industries and sectors with some lesser-known repercussions from COVID-19 (Fig. 1). In these cases, the impacts of the present pandemic often stem from broad paradigm shifts and indirect interrelations between industries. Prominent themes include the 


\section{Advanced Materials Letters www.vbripress.com/aml}

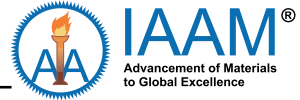

www.iaamonline.com shortening of global supply chains, increasing cooperation between competitors and transitioning to virtual space. These shifts have presented a mix of opportunities and threats to these sectors, some less favorably skewed than others. Accordingly, this article aims to cover the impacts, opportunities and threats of COVID-19 on the medical sector, as well as manufacturing, energy, food and climate change. Most importantly, lessons can be learned from key players in these industries and sectors who have positively transformed the present situation in one way or another. Such learnings must be taken on board and disseminated in order to boost the recovery outlook and adaptability of industries during the present pandemic and those to come.

\section{Manufacturing}

COVID-19 has had a significant impact on the manufacturing sector, which accounts for nearly $16 \%$ of the global economy. China is the world's largest exporter, fulfilling a third of the world's manufacturing needs. The pandemic forced a halt in Chinese manufacturing due to enforced lockdowns to contain the spread of the virus, causing China's Purchasing Manager's Index (PMI) to fall from 50 in January 2020 to 35.7 in February, lower than during the Global Financial Crisis [15]. Since "working from home" is not a viable option for manufacturing plants, China's 300 million migrant workers were quarantined without work [16,17].

Given China's global manufacturing dominance, repercussions of its lockdown are being felt around the world. The United States of America (USA) is expecting a US $\$ 700$ million loss for retailers between March and April alone, due to production and transportation shortages of raw materials from China $[\mathbf{1 8 , 1 9 ]}$. Similarly, $80 \%$ of manufacturers in the United Kingdom are predicting a decline in turnover due to Chinese COVID-19 related lockdown [20]. Automotive, electronics, chemical, energy and airline industries have been the hardest impacted manufacturing sectors. As a result, countries such as the USA and Australia are beginning to turn inwards, focusing on expanding their respective onshore manufacturing industries. Similar initiatives have been previously introduced, such as "Make in India" aimed at stimulating India's local economy (helping with COVID-19 economic recovery) and reducing its dependence on foreign imports. These initiatives however, come with supply chain challenges which must be navigated to find local alternatives for physical and human resources that were previously brought from abroad.

On a positive note, the COVID-19 pandemic has witnessed innovative ideas, collaboration and technology shared among various manufacturing sectors. For example, distilleries are making hand sanitizers and many automotive companies such as Ford Motor Company, General Motors and Tesla have repurposed their skills and resources to build ventilators, testing kits and personal protective equipment for the medical sector [21]. Ford Motor Company teamed up with GE Healthcare providers for manufacturing simplified ventilators [22].
Also, Medtronic publicly shared the design specification for PB 560 ventilators to enable other manufacturers to build these ventilators and facilitate rapid mass production [23].

Furthermore, COVID-19 has drastically changed the perspective towards Industry 4.0 [24]. Prior to the pandemic some manufacturing companies considered Industry 4.0 as a future area of investment with significant potential benefits. Post pandemic, many companies will be inclined to move faster towards developing and implementing Industry 4.0 technology. Building blocks of Industry 4.0 such as artificial intelligence, internet of things, cloud computing, additive manufacturing, data analytics, augmented reality etc., can effectively communicate and minimize challenges raised by future pandemics at a much quicker pace. The fourth industrial revolution involves powerful technology that has proven its potential in sectors such as automotive and aerospace [25]. The current pandemic has accelerated Industry 4.0's applicability in different sectors to combat effects of COVID-19 [26]. Effective implementation of these intelligent technologies [27] could help in battling future emergencies [28]. During pandemics like COVID-19, Industry 4.0 will specifically benefit the health care industry to supply the high demand of customized personal protective equipment and also enables data transfer and tracking of infected patients, providing timely updates and subsequent guideline changes $[\mathbf{2 9 , 3 0 ]}$.

\section{Medical industry}

Undoubtedly, the medical sector has been most directly impacted by COVID-19. Activity in many medical subsectors has significantly increased in comparison to other industrial sectors. This includes most notably, research work involved in vaccine and drug development for treatment and diagnostic systems. COVID-19 testing and diagnosis has been on the rise for every country. As of $28^{\text {th }}$ May 2020, there were more than 1.3 million tests conducted in Australia with $0.5 \%$ returning a positive result. With the large number of tests being carried out in hospitals and diagnostic labs, the demand for quantitative polymerase chain reaction (PCR) assays or serology assays are on the rise. Moreover, there is an increase in mask production and supplies of varying types. This however, has also led to a significant increase in global pollution and waste from the disposal of masks and gloves.

The use of telemedicine has seen a drastic rise since the emergence of COVID-19. Virtual health systems are in wide use to avoid face-to-face contact. For example, the Federal Government of Australia allocated $\$ 100$ million for providing treatments to patients via telephone or online channels in March 2020 [31]. In the US alone, a \$2 trillion relief bill provided cash to most US families, business loans, and a further $\$ 100$ billion for hospitals due to COVID-19 impacts. Anxiety among healthcare workers has increased due to extended work hours and potential exposure to infected patients [32]. Hospitals have had to implement preventive measures such as patients informing 


\section{Advanced Materials Letters www.vbripress.com/aml}

hospitals before arriving with symptoms of respiratory illness. Patient visits to general practitioners (GP) have also drastically reduced [32]. Unemployment among health care professionals has increased, although there has been a rise in the demand for nursing staff. There has also been an increase in online pharmacy services post COVID-19 in both developed and developing countries.

Due to restrictions and social distancing measures, the majority of people are not as physically active [33]. Reduction in physical activities during the pandemic has reduced the occurrence of injuries. On the other hand, social isolation and sedentary lifestyles have led to an increase in mental health problems $[\mathbf{3 3}, \mathbf{3 4}]$. Accordingly, the Federal Government of Australia for example, allocated $\$ 48$ million to mitigate mental health issues in May 2020. Telephone counseling systems have also been implemented in Australia [35], New Zealand [36] and USA [37] to support citizens suffering declined mental health during COVID-19. There has also been a sharp increase in the number of domestic violence incidents. Due to prioritization measures in hospitals, there has been a drastic reduction in elective surgeries, with cosmetic surgeries having halting in many parts of the world. There is also significant reduction in the number of non-essential surgeries [32]. Predominantly, surgeries are only performed in life threatening circumstances.

On a positive note, there has also been a revival of health care facilities throughout the world. For example, intensive care facilities in hospitals have been retrofitted, improved and expanded with more emphasis given on respiratory system care. Funding for healthcare related research has increased. As an example in Australia, \$30 million worth of government funding was announced for COVID-19 related research in March 2020 [31]. These trends clearly demonstrate the priority of medical and related industries, which have overall seen a drastic increase in demand during the COVID-19 pandemic.

\section{Climate change}

The outbreak of COVID-19 has had significant impact on our day-to-day activities and life, however its impact on the environment and climate change is less known. Guidelines issued by various governments during this pandemic have altered the pattern of energy demand worldwide. Several small scale and large-scale industries have stopped functioning, resulting in decreased waste emission and use of fossil fuels and other energy sources to meet power demands (Fig. 2).

Since the outbreak of COVID-19 many countries with large populations such as China, USA, UK, Australia, India, etc. went into a partial or full lockdown for extended periods [38]. As a part of this, governments restricted free movement of their citizens and have banned all gatherings, resulting in low use of vehicles of any kind (e.g. cars, busses and airplanes), thereby significantly reducing the emission of pollutant gases produced by transport vehicles. This population confinement has also led to drastic changes in energy use and carbon dioxide $\left(\mathrm{CO}_{2}\right)$ emissions [39]. For instance, data from the Sentinel-5P satellite has shown that nitrogen dioxide air pollution levels have nose-dived across Europe during this pandemic. Although the significance of this decrease in the long-term may be uncertain, current decreases in air pollution levels are positively affecting health in general, which can be regarded as a good thing [40]. Water quality and health of the Ganga River in India has seen significant improvement since a full lockdown as imposed on 24 March 2020, reducing dumping of industrial waste into the river [41]. Similarly, lockdown in Italy has resulted in clear and pollution free canals in Venice canals due to the lack of tourists and water traffic [42].

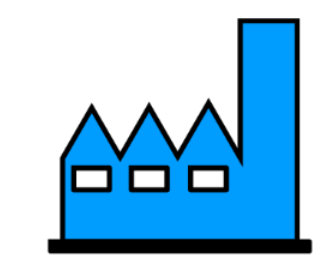

Industrial pollution

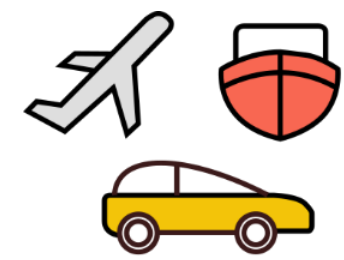

Transport pollution

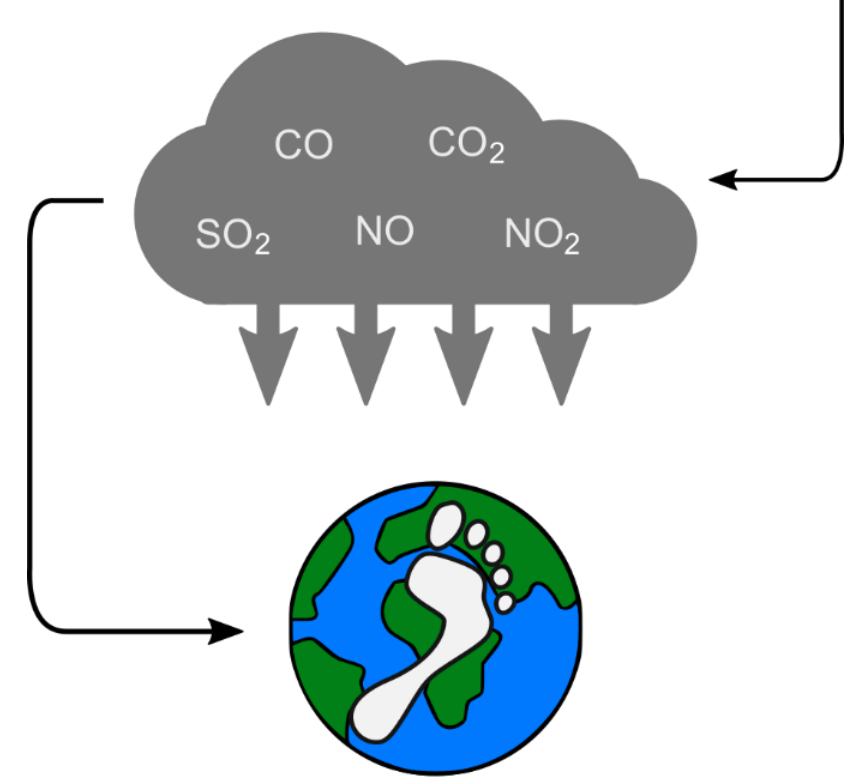

Fig. 2. Schematic representation of the effect COVID-19 has had on the environment. Working from home and travel bans has reduced industrial and vehicular pollution, lowering the release of primary pollutants in the atmosphere. This has ultimately produced a lower carbon footprint and cleaner environment.

Essentially, COVID-19 has demonstrated what can be done differently, by forcing changes in behavior which may remain once restrictions have lifted. For example, interstate and international business travel may decrease (now that online meetings and conferences have become so common) [43], causing lower emissions by air travel. Even though COVID-19 has caused unprecedented disruption to human life, it has resulted in very positive short-term impacts on the health of plant Earth. However, while $\mathrm{CO}_{2}$ emissions are predicted to fall by $5 \%$ in 2020 as a direct result of 


\section{Advanced Materials Letters www.vbripress.com/aml}

COVID-19, experts warn that greenhouse gas emission reductions seen during the first half of 2020 are likely to be temporary and short-lived [44].

\section{Energy industry}

Energy commodities have been affected by the COVID-19 pandemic as residential and industrial consumption profiles experience unprecedented and unexpected change [37]. Sufficient energy supply during the COVID-19 pandemic is crucial for health sectors (including intensive care units [45], ventilators, incubators and sterilization $[\mathbf{4 6 , 4 7 ]}$ ) and other essential services, as well as maintaining day-to-day life [36].

The transportation sector usually accounts for large proportions of a country's energy demands, for example $69 \%$ of the total petroleum fuel consumed in the USA is by its transportation sector [48]. With public mobility drastically reduced [36], almost all modes of transportation in most countries have been affected by safety measures taken to mitigate the spread of COVID-19. China reported a $65 \%$ drop in passenger transport and $73.6 \%$ drop in civil aviation in April compared to the same period in 2019 [49]. The reduction in transport and travel has consequently reduced fuel consumption causing "demand and supply shock" [37] resulting in record-breaking drops in crude oil prices. For example, the price of Brent crude oil has dropped more than $8 \%$, bringing the price of one barrel down to as low as US $\$ 20$, its lowest price in 18 years [50], and West Texas Intermediate (WTI) oil halved in May 2020 compared to 2019. Interestingly, natural gas has also dropped in price compared to 2018 and 2019 [37]. At this stage, the effect of the pandemic on coal prices are not yet evident due to pre-existing falling gas prices [51].

The aviation industry, which accounts for $9 \%$ of global petroleum fuel consumption has also been significantly affected by COVID-19, as many countries opted to close their borders [52]. As a result of this, air passenger transport has plummeted, with the airline industry forecasted to shrink by $65 \%$ in the second quarter of 2020 , needing a significant period to recover [53]. The USA reported a more than $50 \%$ reduction in international and domestic passengers for the month of March 2020 compared to 2019 [53]. With evidence suggesting aircrafts as potential transmission sources of COVID-19, the airline industry will face more challenges in the coming months and years as customers fear travelling by air $[\mathbf{5 4 , 5 5}]$. Some industry experts speculate that due to the reduction in air travel demand and aviation fuel production, about one third of airlines will not survive this massive loss of revenue [56], causing long-term decline in fuel demand that will raise major problems in the energy sector.

The COVID-19 pandemic has also led to the closure or reduction in capacity of many factories and production plants due to social distancing measures and limitations to supply chains and logistics. Manufacturing industries consumes $18 \%$ of total energy consumption in Australia [57], and 24\% in the US [55]. Reduced energy consumption by industrial sectors has been observed in many parts of the world [56,58]. Moreover, recreational activities have been partially or completed restricted by governments, closing theme parks, pubs, night clubs, and cinemas across the world. Ultimately, global electricity consumption has been drastically reduced following COVID-19 related lockdown measures. The International Energy Agency (IEA) reported that electricity consumption in Italy and Spain has reduced by more than $25 \%$ while that of the UK, India, Germany and France were above 20\% [59]. Net electricity generation in the USA for the month of March was reduced by $5.6 \%$ compared to the previous year [56]. Although electricity consumption by residential consumers decreased by $6 \%$ in the US, consumption by industrial sectors grew by $1 \%$. On the contrary, the overall electricity consumption in the UK was reduced by $1.5 \%$ in the first quarter of 2020 compared to 2019 , but consumption by industrial sectors reduced by $5 \%$, while domestic consumption increased by $1.4 \%$ [58]. Overall electricity consumption in Australia has not changed after lockdown was imposed [60]. Compared to the USA, working from home arrangements was widely adopted in Australia, which may have resulted in increased energy consumption at a domestic level, though certain industries have reduced electricity demands. Some governments have provided relief to their citizens during this time, with support measures including fully waived (Indonesia and Italy) or discounted electricity bills (Malaysia), reduced payment security (India), deferred electricity payments (German and Australia) and uninterrupted power supply (Australia) [35].

This sudden variation in energy demand has shifted the balance of energy sources used for electricity generation. On the bright side, China and India reported reduced electricity demand, reducing consumption of coal for electricity generation [61]. However, renewable energy generation infrastructure development projects (which can lower electricity costs) have been delayed due to the pandemic, despite the IEA and the International Renewable Energy Agency urging investment in renewable resources be maintained $[62,63]$. Insufficient production of solar panels and materials due to cost-cutting measures and halted growth plans are causing delays in clean energy projects in China, Australia, India Southeast Asia $[64,66]$. For example, wind and solar power generation projects (up to $3 \mathrm{GW}$ ) are reported to be delayed in Australia [67].

Shifts in energy demand due to COVID-19 will put short and long-term strain on the energy sector. Temporary shutting down of oil refineries are likely to be warranted to mitigate surplus production. In addition, temporary shutdowns around the globe will have substantial impacts on the petroleum refinery sector, along with the supply chain of crude oil, including tankers and bunkering facilities. Typically, multiple sources are used for electricity generation such as coal, petroleum oil, nuclear power and renewable energy however, careful balance is required when combining numerous sources for electricity generation. Power grid balancing will pose challenges for suppliers and regulators as the base load fluctuates in an unpredictable manner. These fluctuations in electricity 


\section{Advanced Materials Letters www.vbripress.com/aml}

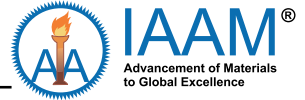

www.iaamonline.com demand will pose severe challenges to many countries, and balance will be required between government revenue and monetary support to citizens to manage short and long-term economic shock [68]. It is recommended that going forward, domestic electricity distribution develop an "Energy Emergency Pandemic Plan" in the event of future global pandemics [35].

\section{Food industry}

The food sector, including distribution and retailing, has been under severe strain due to panic-buying and stockpiling of non-perishables during COVID-19 [69]. This has led to community unease with regards to shortages of products such as meat, flour, milk, pasta, rice etc. [70]. While at-home food and beverage consumption has increased, out-of-home consumption (which generates the highest financial margin) has essentially stopped [71], due to imposed government restrictions and lockdowns. Furthermore, food banks have also been affected by food stockpiling as donations have lessened. Many have been weary of the lack of access to food, forcing additional restrictions and purchasing limits, and priority for vulnerable citizens $[\mathbf{5 7 , 7 2}]$. Online ordering of packaged food, meals and beverages have seen an upsurge in demand [73] due to low in-store supply. Independent supermarkets have also been affected by high demand. Local stores have implemented measures including free product delivery, minimising panic-buying and limiting the number of customers in-store to avoid over-crowding. Some independent supermarkets have also expanded their supplier partnerships to meet demand and avoid food shortage [60].

The global food industry relies on food and supply chains, sectors which have been hard hit and disrupted during the pandemic, due to sudden increases in demand of in-store groceries and reduction in out-of-home dining. The Asia-Pacific region and Europe have been the most impacted due to the high number of COVID-19 cases in these regions (e.g. China, Japan, Italy and Spain) [73]. Food supply chains have been largely disrupted due to lockdowns and reductions in exports (as a result of border closures). For example, Coca Cola Co. experienced delays in production caused by a loss of sucralose supply from the US and China [73]. Border travel restrictions have also had an impact on the normal seasonal cycle of migrant farm workers. In addition, some countries such as India, Vietnam, Russia and Kazakhstan have banned or capped foreign exports of food to sustain their own populations. This is known as 'food protectionism' and while it may provide some relief to local food supply chains, it causes a global surge in food prices [74]. In recent years, episodes of extreme weather events, spread of disease (such as swine fever) and increased insect activity have caused major food price spikes (up to $60 \%$ increase) [74]. It is predicted that COVID-19 will have similar effects, especially in developing countries.

In light of these challenges to provide adequate and nutritious food at times of pandemics, governments are being urged to define, finance, and distribute food baskets that support the health needs of the population, ensuring the use of local products, thereby minimizing reliance on food imports and wastage [75,76]. The influence of this pandemic on nutrition and dietary intake has gone beyond the community to national and global levels. Given stockpiling of non-perishables and imposed public restrictions, the supply and demand of fresh fruit and vegetables are consequently unbalanced. Interestingly, as a result of COVID-19, the overall health of an individual will be a function of the awareness of their choices, unity within the community, attentiveness of the government and universal commitment towards overcoming the threat of this pandemic.

It is expected that once out-of-home consumption picks up, combined with the reopening of the hospitality industry, the impact on food and beverage companies will normalise, however full economic recovery may take weeks to months at least. From this pandemic, learnings and mitigation techniques can be developed, including supply chain risk management, alternative route-to-market channels and ways to support key suppliers to fulfil demand in peak buying scenarios such as we've seen during COVID-19 [71].

\section{Conclusion}

The socio-economic challenges posed by the COVID-19 pandemic necessitates for various types of reformations and transformations in almost every industrial sector. Strategies of many industries involve redesigning and reprioritizing. Similarly, some novel strategies may directly assist in fighting COVID-19 especially for the medical sector. Nanotechnology may offer a solution to inhibit the transmission of SARS-CoV-2. We have recently shown that surfaces with nanoscale topography can significantly reduce respiratory syncytial virus and rhinovirus [77]. We have also shown that a range of nanostructured surfaces such as titanium and aluminium kill bacterial cells [78-84]. It is believed that such nanoscale surfaces will also be able to inactivate the SARS-CoV-2. Implementation of antibacterial and antiviral surfaces in key areas such as hospitals (surgical equipment, general surfaces), healthcare environments, transportation vehicles and textile industries etc. will reduce the spread of infectious disease thereby mitigating the risk of wide-spread devastation seen as a direct result of COVID-19.

While impacts of COVID-19 to industries such as education, entertainment, tourism, and hospitality are well known, this review summarizes and highlights lesserknown effects of COVID-19 on various industrial sectors. At this stage, the full extent of damage is not yet known, however as this situation continues to evolve, further details and consequences will be revealed. While there has been much global devastation caused by COVID-19, it has also brought improvements to Earth's environment, improving levels of greenhouse gas emissions, and initiated rapid and novel manufacturing methods (e.g. ventilators). COVID-19 will be known in the future as a catalyst for changing the 


\section{Advanced Materials Letters www.vbripress.com/aml}

way we think about disease control, medical capabilities, energy supply and demand, food supply, manufacturing and foreign imports. Through this pandemic, there will be many lessons to learn and opportunities to grow and adapt to prepare for potential future pandemics.

\section{Keywords}

COVID-19, SARS-CoV-2 virus, Social distancing, Industries.

\section{Funding}

This work is supported by the Australian Research Council Discovery Grant [DP180101098], Advance Queensland Industry Research Fellowship, Konica Minolta, and Bionics Queensland.

\section{References}

1. Cucinotta, D.; Vanelli, M.; Acta Biomed, 2020, 157.

2. Matsuo, A.; Chiba, H.; Takahashi, H.; Toyoda, J.; Abukawa, H., Odontology, 2010, 98, 85 .

3. Cheng, H. Y.; Jian, S. W.; Liu, D. P.; Ng, T. C.; Huang, W. T.; Lin, H. H., High transmissibility of COVID-19 near symptom onset. medRxiv 2020, 2020.03.18.20034561.

4. Liu, Y.; Gayle, A. A.; Wilder-Smith, A.; Rocklöv, J., J. Travel Med. 2020, 27.

5. Lau, H.; Khosrawipour, V.; Kocbach, P.; Mikolajczyk, A.; Schubert, J.; Bania, J.; Khosrawipour, T., J. Travel Med. 2020, 27.

6. Armocida, B.; Formenti, B.; Ussai, S.; Palestra, F.; Missoni, E.; Lancet Public Health, 2020, 5, e253.

7. Legido-Quigley, H.; Asgari, N.; Teo, Y. Y.; Leung, G. M.; Oshitani, H.; Fukuda, K.; Cook, A. R.; Hsu, L. Y.; Shibuya, K.; Heymann, D.; The Lancet, 2020, 395, 848.

8. Anderson, R. M.; Heesterbeek, H.; Klinkenberg, D.; Hollingsworth, T. D., The Lancet, 2020, 395, 931.

9. McKee, M.; Stuckler, D.; Nat. Med., 2020, 26, 640.

10. Gössling, S.; Scott, D.; Hall, C. M.; J. Sustain. Tour., 2020, 1.

11. Iacus, S. M.; Natale, F.; Santamaria, C.; Spyratos, S.; Vespe, M.; Saf. Sci., 2020, 129, 104791 .

12. Cassells, R.; Duncan, A.; Dockery, M.; Kiely, D.; Mavisakalyan, A.; Potential job losses in the COVID-19 pandemic. Bankwest Curtin Economics Centre, Curtin University: Bentley, 2020, p5.

13. Toresdahl, B. G.; Asif, I. M.; Sports Health, 2020, 12, 221.

14. Zhang, W.; Wang, Y.; Yang, L.; Wang, C.;J. Risk Financial Manag., 2020, 13, 55.

15. Coronavirus: China manufacturing collapse confirmed as private sector factory survey hits record low. https://www.scmp.com/weekasia/politics/article/3083331/australia-concerned-over-reports-usmay-have-leaked-documents (accessed 16 May 2020).

16. Nicola, M.; Alsafi, Z.; Sohrabi, C.; Kerwan, A.; Al-Jabir, A.; Iosifidis, C.; Agha, M.; Agha, R.; Int. J. Surg., 2020, 78.

17. Prescott, K.; Chinese manufacturing hits record low amid coronavirus outbreak. https://www.bbc.com/news/business$\underline{51689178}$ (accessed 16 May 2020).

18. Bell, H.; What you need to know about Coronavirus \& your supply chain. https://www.zencargo.com/resources/coronavirussupply-chain/ (accessed 16 May 2020).

19. Thomas, L.; Coronavirus wreaks havoc on retail supply chains globally, even as China's factories come back online. https://www.cnbc.com/2020/03/16/coronavirus-wreaks-havoc-onretail-supply-chains-globally.html (accessed 16 May 2020).

20. Plastics Trade Body Publishes First Study of Coronavirus Impact on UK Manufacturing. https://www.bpf.co.uk/article/plasticstrade-body-publishes-first-study-of-coronavirus-impact-1602.aspx (accessed 16 May 2020).

21. Morrison, S.; Ford and GM are making tens of thousands of ventilators. It may already be too late. $\mathbf{2 0 2 0}$.

22. Worley, S.; Teaming Up: GE Healthcare And Ford Partner To Quickly Manufacture Ventilators For COVID-19 Patients. 2020.

23. Gupta, S.; Innovations in the Sphere of Ventilators-Arsenal to Fight COVID-19.

24. Manufcaturer, T.; What is the future for Industry 4.0 in the post Covid-19 paradigm? 2020.
25. Paritala, P. K.; Manchikatla, S.; Yarlagadda, P. K. D. V.; Procedia Eng. 2017, 174, 982.

26. Antova, G.; COVID-19 set to accelerate Industry 4.0. Australia Manufacturing: Australia, 2020.

27. Vaishya, R.; Haleem, A.; Vaish, A.; Javaid, M.; J. Clin. Exp. Hepatol., 2020.

28. Javaid, M.; Haleem, A.; Vaishya, R.; Bahl, S.; Suman, R.; Vaish, A.; Diabetes Metab. Syndr., 2020, 14, 419.

29. Singh, R. P.; Javaid, M.; Haleem, A.; Suman, R. J. D.; Research, M. S. C.; Reviews, Internet of things (IoT) applications to fight against COVID-19 pandemic. 2020.

30. Singhal, N.; Prakash, S. J. A. a. S., A Fight Against COVID-19: Major IT Trends. 2020.

31. Gulseven, O.; Al Harmoodi, F.; Al Falasi, M.; ALshomali, I., How the COVID-19 Pandemic Will Affect the UN Sustainable Development Goals? Available at SSRN 35929332020.

32. Cheung, T.; Fong, T. K. H.; Bressington, D.; J. Psychiatr. Ment. Health Nurs., 2020, 1-3.

33. Chen, P.; Mao, L.; Nassis, G. P.; Harmer, P.; Ainsworth, B. E.; Li, F.; J. Sport Health Sci., 2020, 9, 103.

34. Fallon, K.; Aust. J. Gen. Pract. 2020, 49.

35. Qarnain, S. S.; Muthuvel, S.; Bathrinath, S.; Mater. Today: Proceedings, 2020.

36. Broto, V. C.; Kirshner, J.; Nat. Energy, 2020, 1.

37. Hauser, P.; Anke, C.; López, J. G.; Möst, D.; Scharf, H.; Schönheit, D.; Schreiber, S., The Impact of the COVID-19 Crisis on Energy Prices in Comparison to the 2008 Financial Crisis.

38. Chakraborty, I.; Maity, P.; Sci. Total Environ. 2020, 728.

39. Le Quéré, C.; Jackson, R. B.; Jones, M. W.; Smith, A. J. P.; Abernethy, S.; Andrew, R. M.; De-Gol, A. J.; Willis, D. R.; Shan, Y.; Canadell, J. G.; Friedlingstein, P.; Creutzig, F.; Peters, G. P.; Nat. Clim. Change, 2020.

40. Wilks, J.; Ging, J.-P. Coronavirus and climate: how much impact is the current lockdown really having on our environment? https://www.euronews.com/2020/04/13/covid-19-and-climatehow-much-impact-is-the-current-lockdown-really-having-on-ourenvironm (accessed 28 May 2020).

41. Coronavirus Lockdown: Health Of River Ganga Improves. https://www.bloombergquint.com/coronavirus-outbreak/lockdownhealth-of-river-ganga-improves (accessed 30 May 2020).

42. Venice canals run clear as coronavirus lockdown leaves city free of tourists. https://www.abc.net.au/news/2020-03-19/venice-canalsrun-clear-amid-coronavirus-lockdown/12071378 (accessed 30 May 2020).

43. Schuijers, L. Covid-19 is an opportunity to reset our environmental future. https://pursuit.unimelb.edu.au/articles/covid-19-is-anopportunity-to-reset-our-environmental-future (accessed 30 May 2020).

44. Covid-19: Biggest drop in $\mathrm{CO} 2$ emissions since WWII but little impact on climate change. http://www.rfi.fr/en/international/ 20200403-covid-19-biggest-drop-in-co2-emissions-since-wwii-butlittle-impact-on-climate-change (accessed 30 May 2020).

45. Stafford, R. E.; Morrison, C. A.; Godfrey, G.; Mahalu, W.; Global Heart, 2014, 9, 319.

46. Roth, S.; Silva, F.; 3 ways investing in energy makes people healthier. https://blogs.adb.org/blog/3-ways-investing-energymakes-people-healthier (accessed 30 May 2020).

47. Suhlrie, L.; Bartram, J.; Burns, J.; Joca, L.; Tomaro, J.; Rehfuess, E.; PloS one 2018, 13, e0200261.

48. Administration, U. S. E. I. Monthly Energy Review; U.S. Energy Information Administration, 2020.

49. China, N. B. o. S. o. National Data; National Bureau of Statistics of China, 2020.

50. Lora, J.; Palumbo, D.; Brown, D. Coronavirus: A visual guide to the economic impact. https://www.bbc.com/news/business-51706225 (accessed 29 March 2020).

51. Agency, I. E.; Coal, 2019.

52. Benito, A.; Gustavo, A.; Energy efficiency in air transportation. Butterworth-Heinemann: Oxford, United Kingdom, 2018.

53. Pearce, B.; COVID-19 Updated impact assessment. https://www.iata.org/en/iata-repository/publications/economicreports/third-impact-assessment/. 


\section{Advanced Materials Letters www.vbripress.com/aml}

54. Lau, H.; Khosrawipour, V.; Kocbach, P.; Mikolajczyk, A.; Ichii, H.; Zacharski, M.; Bania, J.; Khosrawipour, T.; J. Microbiol. Immunol. Infect., 2020.

55. Eldin, C.; Lagier, J. C.; Mailhe, M.; Gautret, P., Probable aircraft transmission of Covid-19 in-flight from the Central African Republic to France. Travel medicine and infectious disease 2020, 101643.

56. Tunik, T. One-third of all airlines will not survive the pandemic, says Wizz Air CEO. https://www.calcalistech.com/ctech/articles/ 0,7340, L-3827780,00.html (accessed 29 Mar 2020).

57. Coronavirus: Food bank shortage blamed on panic buying. https://www.bbc.com/news/uk-england-london-51837892 (accessed 23 Mar 2020).

58. (UK), N. S. Energy Trends: UK Electricity; National Statistics, 2020.

59. Agency, I. E. Reductions of electricity demand after implementing lockdown measures in selected countries, weather corrected, 0 to 68 days. https://www.iea.org/data-and-statistics/charts/reductions-ofelectricity-demand-after-implementing-lockdown-measures-inselected-countries-weather-corrected-0-to-68-days (accessed 29 March 2020).

60. Meierhans, J.; Coronavirus: What are independent supermarkets doing to help? https://www.bbc.com/news/uk-england-51947391 (accessed 23 March 2020).

61. Agency, I. E. COVID-19 impact on electricity; International Energy Agency: Paris, 2020.

62. Birol, F.; The coronavirus crisis reminds us that electricity is more indispensable than ever. https://www.iea.org/commentaries/thecoronavirus-crisis-reminds-us-that-electricity-is-moreindispensable-than-ever (accessed 30 May 2020).

63. La Camera, F.; Staying on Course: Renewable Energy in the Time of COVID-19. https://www.irena.org/newsroom/pressreleases/ 2020/Apr/Staying-on-Course-Renewable-Energy-in-the-time-ofCOVID19 (accessed 29 May 2020).

64. Solberg, E.; Akufo-Addo, N. A. D.; Why we cannot lose sight of the Sustainable Development Goals during coronavirus. https://www.weforum.org/agenda/2020/04/coronavirus-pandemiceffect-sdg-un-progress (accessed 29 May 2020).

65. Penn, I.; Oil Companies Are Collapsing, but Wind and Solar Energy Keep Growing. https://www.nytimes.com/2020/04/07/business/ energy-environment/coronavirus-oil-wind-solar-energy.html (accessed 28 May 2020).

66. Uetz, A. M.; Miller, V. L.; Artkin, J. R.; Managing the Commercial Impact of the Coronavirus: Implications for the Energy Industry. https://www.natlawreview.com/article/managing-commercialimpact-coronavirus-implications-energy-industry (accessed 31 May 2020).

67. Parkinson, G.; COVID-19 pandemic could delay up to $3 \mathrm{GW}$ of Australia wind and solar projects. https://reneweconomy.com.au/ covid-19-pandemic-could-delay-up-to-3gw-of-australia-wind-andsolar-projects-74189/ (accessed 29 March 2020).

68. Sen, A.; A double-edged sword for Indian's energy sector? The Oxford Institute for Energy Studies, 2020.

69. Bachelor, L.; MPs in plea to government over UK's Covid-19 stockpiling. https://www.theguardian.com/world/2020/mar/21/mpsplea-government-uk-covid-19-stockpiling-coronavirus (accessed 23 March 2020).

70. Coronavirus: Online shopping website Ocado suspends service. https://www.bbc.com/news/business-51941987 (accessed 23 March 2020).

71. Pieters, L.; Understanding the Sector Impact of COVID-19: Consumer Products: Food \& Beverage, 25 March 2020.

72. Coronavirus stockpiling 'will hit vulnerable', says foodbank boss. https://www.bbc.com/news/uk-england-beds-bucks-herts-51856592 (accessed 23 March 2020).

73. Global Food \& Beverages Industry and the Effects of COVID-19 Analysis of Regional Regulations and Other Government Policies. https://www.businesswire.com/news/home/20200415005321/en/Gl obal-Food-Beverages-Industry-Effects-COVID-19-- (accessed 30 May 2020).

74. Rienhart, C. M.; Subbaraman, R.; How can we prevent a COVID-19 food crisis? https://www.weforum.org/agenda/2020/05/preventinga-covid-19-food-crisis/ (accessed 30 May 2020).

75. Naja, F.; Hamadeh, R.; Eur. J. Clin. Nutr., 2020.
76. Distribution of emergency food during a pandemic. Tool $11 \mathrm{Ed}$.; Organization, P. A. H., Ed. 2020.

77. Hasan, J.; Xu, Y.; Yarlagadda, T.; Schuetz, M.; Spann, K.; Yarlagadda, P. K. D. V.; ACS Biomater. Sci. Eng., 2020.

78. Jaggessar, A.; Shahali, H.; Mathew, A.; Yarlagadda, P. K. D. V.; J. Nanobiotechnology, 2017, 15, 64.

79. Jaggessar, A.; Mathew, A.; Wang, H.; Tesfamichael, T.; Yan, C.; Yarlagadda, P. K. D. V.; J. Mech. Behav. Biomed. Mater., 2018, 80, 311.

80. Shahali, H.; Hasan, J.; Mathews, A.; Wang, H.; Yan, C.; Tesfamichael, T.; Yarlagadda, P. K. D. V.; J. Mater. Chem. B., 2019, 7,1300 .

81. Hasan, J.; Roy, A.; Chatterjee, K.; Yarlagadda, P.; ACS Biomater. Sci. Eng., 2019, 5, 3139.

82. Jaggessar, A.; Yarlagadda, P. K. D. V.; Mater. Sci. Eng. C, 2020, 108.

83. Jaggessar, A.; Mathew, A.; Tesfamichael, T.; Wang, H.; Yan, C.; Yarlagadda, P. K. D. V.; Molecules, 2019, 24.

84. Velic, A.; Mathew, A.; Hines, P.; Yarlagadda, P.; J. Mech. Behav. Biomed. Mater., 2019, 91, 416 . 